\title{
Edward B. Harvey, ed. The Lansdowne Era: Victoria College, 1946-1963.
}

Montreal and Kingston: McGill-Queen's University Press, 2008. 199 pp.

\section{Charles Levi}

Toronto, Ont.

In 1993, Peter Lawson Smith published A Multitude of the Wise: UVic Remembered. In his introduction, he posited three possible types of institutional history for Canadian universities, and suggested that each university should have one of each type. One of the types was to be "an anecdotal and lavishly illustrated publication for the alumni market, liberated from the constraints of scholarship: lots of laughs, a few tears, and a place of honour on the coffee-table"(5). When Smith died in 2006, the alumni association of the University of Victoria commissioned exactly such a book, the proceeds of which would go to provide student awards in his honour.

Recent practice has been to publish alumni reminiscences in-house or through some vanity press, and to sell them to alumni and the larger academic libraries which attempt to be completionist. The Lansdowne Era, however, has been published by an academic press, which implies that the author and the academic press believed there was larger interest in the pre-history of the University of Victoria between 1946 and 1963. This leads to two questions: has the involvement of an academic press improved the quality of the work, and, given the placement of this review, is the book of any value for a historian of education? The answer to both questions, sadly, is no. This book is a poor effort, and historians of education would be well-advised to instead invest in a second-hand copy of the more superior A Multitude of the Wise.

The book is divided into four parts - a section on "perspectives," a section on "reflections," a listing of the citations of the winners of the University of Victoria Distinguished Alumni Awards, and a small collection of in memoriam essays to deceased alumni. The historian and reviewer need only concern themselves with the "perspectives" and "reflections." The reflections certainly reflect, but the perspectives provide no perspective. 
Edward Harvey's introduction suggests that "the Lansdowne period was a major precursor to the University of Victoria. This evolution was fostered by major economic, demographic, and social changes that exerted a transformative effect on the people and institutions of Canada" (3). If Harvey had instructed his writers to follow in this vein, the book might have been quite informative, but even he cannot sustain the argument for more than two pages. His contributors, meanwhile, focus on various hirings, the construction of buildings, and members of various sports teams. Martin Seggers does provide a valuable contribution to the study of campus architecture - his companion piece on the Victoria Art Collection, however, is merely a catalogue of works with no analysis. Truly to be avoided are Kenneth McCulloch's piece on men's sports and Susan Yates' piece on women's sports, both of which provide endless lists of teams and team members. On the one event that cries out for more detail — the remarkable 1958 Canadian championship in men's basketball — McCulloch says nothing about how the victory was secured and instead mentions the career accomplishments of the team members in later life (73-74).

In both this section and in the "reflections" to follow, an active editor would have deleted the repetition of population statistics for British Columbia within Peter Ross's essay $(35,41)$, and either of two references that an Athletic Council was formed in 1956 (89, 144). Editing would have also removed the suggestion that 1958 was "before" organized student protest in Canada - a claim which the editor himself makes (152)! Not only is this not true for Canada, it is not true even for the University of Victoria, which had an organized student protest in 1946 (Smith, 96). Editing would also have prevented Carole MacDonald discussing a student protest of 1958 without once mentioning what actually happened and why it was important (152-154).

The reflections do have some value. Brian Little writes an excellent piece in which he contemplates the biology of a small college as a nurturer of "Strange Creatures" (158-166). This novel thesis, eruditely articulated, deserves a wider audience. Jane Hedley provides two very good pages on the struggles female students went through in the early 1960s to decode the "mixed messages" they received about motherhood vs. scholarship (184-185). If the book had been full of these comments, and not with Lorna Marsden's bizarre name-dropping of Charles Mingus (171), and Timothy Price's infatuation with the word "business" (which he uses fourteen times in less than two reflection-free pages of text), then the book as a whole might have made some claim to lasting value for the social history of higher education.

In his conclusion Harvey briefly channels Levitt's Children of Privilege without openly citing it, but then quickly detours into his personal connections with refugee students from Eastern Europe who attended the college. He then concludes that Victoria College fostered the qualities of "a lifelong love of learning" and "gave us the chance to develop and broaden our social skills" (198). This, Harvey calls, the "enduring tradition" of the College (199). This reviewer can only respond that in fact this was the purpose of undergraduate education in the entirety of Canada until the 1970s. The alumni of Victoria College deserve commendation for raising money to honour the memory of Peter Smith - historians of education can better honour this memory by purchasing and reading A Multitude of the Wise. 